\title{
Acinar cell neoplasms of the exocrine pancreas
}

\author{
J. N. WEBB
}

From the Department of Pathology, Western General Hospital, Edinburgh, and the University of Edinburgh

SYNOPSIS The pathological features of 12 acinar cell neoplasms of the pancreas are described; these comprise 11 carcinomas, of which seven were pure acinar cell growths and four were mixed acinar and ductal carcinomas, and one adenoma. These tumours occurred in a series of 105 during the period 1962-75. Thrombotic endocarditis developed in three out of the 11 carcinoma cases. The distinctive histological features of these neoplasms and the means of differentiating them from anaplastic carcinomas and certain other carcinomas, for example, islet cell carcinomas, oat cell carcinomas, and carcinoid tumours, are discussed. The poor prognosis of pancreatic cancers is emphasized, and reasons are put forward for believing that future epidemiological studies may need to take account of the histological types of pancreatic carcinoma.

Carcinoma of the exocrine pancreas is a common form of cancer and is rapidly fatal in the great majority of cases (Halpert et al, 1965; Moldow and Connelly, 1968). According to the Registrar General's mortality statistics for England and Wales, 5339 people died of cancer of the pancreas in 1973 (Ofice of Population Censuses and Surveys, 1976). In spite of the fact that this condition must have one of the worst survival figures of all forms of cancer it is only recently that there has been a re-awakening of interest in the epidemiology (Wynder, 1975) and experimental aspects of the subject (Longnecker and Crawford, 1974; Pour et al, 1974; Longnecker and Curphey, 1975).

The great majority of pancreatic carcinomas are adenocarcinomas of ductal origin. Some carcinomas are entirely anaplastic. A distinctive histological type of carcinoma, accounting for a small proportion of all cases, is derived from the acinar cells. Willis (1967) maintains that no useful purpose is served by classifying pancreatic carcinomas accordding to their supposed origin from ductal or acinar epithelium. On the other hand, it might be helpful to delineate the acinar cell carcinomas since future epidemiological studies may have to take account of the distinctive histological types. It is of interest to note in this connection that Longnecker and Crawford have induced acinar cell neoplasms in rats by means of the carcinogenic agent, azaserine.

I have studied 12 acinar cell neoplasms of the pancreas, comprising 11 carcinomas and one

Received for publication 20 June 1976 adenoma. The acinar cell carcinomas were taken from a series of 105 cases of carcinoma of the exocrine pancreas seen at the Western General Hospital, Edinburgh during the 14-year period 1962-75. The distinctive histology and ultrastructure of these neoplasms are described. An acinar cell adenoma is also described as it would appear that this is an extremely rare neoplasm in humans (Frantz, 1959; Garcia et al, 1975) although it occurs spontaneously in rats (Rowlatt and Roe, 1967).

\section{Material and method}

The files of the Department of Pathology, Western General Hospital, Edinburgh were searched for cases of carcinoma of the pancreas for the years 1962-75. The diagnosis was considered acceptable in 105 cases. Necropsies were carried out on 78. In the remaining 27 cases, the diagnosis was based on the laparotomy findings and pancreatic biopsy. Partial pancreatectomy was carried out in three of these 27 patients. The histology of all the cases was reviewed. The following stains were also used in some cases where they were deemed appropriate: PAS, Lendrum's phloxine-tartrazine, Gomori's aldehyde fuchsin for $B$ islet cells, and acidified PTAH and a modified Bodian's silver method for A islet cells.

Two cases ( 9 and 11) were studied by electron microscopy by a standard processing method. The tissue from case 9 was obtained at necropsy from the primary pancreatic growth, and in case 11 a piece of tissue from a biopsy of a metastasis in the liver was processed for electron microscopy. 


\section{Results}

Table I summarizes the main findings of the series of 105 pancreatic carcinomas. The majority of the neoplasms were ductal adenocarcinomas, often with an abundant stroma; mucin-secretion was a common feature. Two tumours were intracystic papillary carcinomas and six were frankly anaplastic. There were 11 acinar cell carcinomas ( 7 pure and 4 mixed ductal and acinar). While some ductal adenocarcinomas may contain anaplastic areas (which might conceivably be of acinar origin), the mixed tumour referred to here implies a tumour with distinct areas of differentiated ductal and acinar elements.

Table II summarizes the main features of the 12 patients with an acinar cell neoplasm (11 carcinomas and 1 adenoma). Necropsies were carried out in all these cases.

\section{HISTOLOGY}

Pure acinar cell carcinoma (figs 1 to 7 )

The cells are round, columnar or triangular; they have regular round or oval nuclei, often basal in position. The nuclei are frequently hyperchromatic (figs 1, 2, 4, and 5) but may have a more open chromatin pattern. In case 9 (fig 7), the cells were more pleomorphic and the nuclei were vesicular with a prominent nucleolus. In general, nucleoli are inconspicuous in these neoplasms. Mitotic figures are usually sparse. The cytoplasm stains either purplish in haematoxylin and eosin preparations or else is eosinophilic. Occasionally eosinophilic granules can be identified in well fixed sections. The cells are arranged in acinar or alveolar groups (figs 1 and 4), solid clumps or cords (figs 3, 5, and 6). Microtubules containing PAS positive material (mucin) can sometimes be identified (fig 5). The amount of stroma is variable. It is often scanty but can be plentiful.

\section{Mixed ductal and acinar carcinoma}

The histology of the acinar component is identical with the pure acinar cell neoplasms.

\section{Acinar cell adenoma (figs 8 and 9)}

This was an incidental finding at necropsy in a 49-year-old man whose death was due to massive pontine haemorrhage complicating hypertensive heart disease. A routine section from the body of the pancreas revealed a tiny encapsulated tumour, $1 \mathrm{~mm}$ in diameter. The histology consists of tumour cells forming acini and cords set in a fibrous stroma. The cells are round, columnar or triangular and have

Table I Carcinomas of exocrine pancreas 1962-75

\begin{tabular}{|c|c|c|c|c|c|c|c|c|c|}
\hline \multirow[t]{2}{*}{ Carcinoma type } & \multirow[t]{2}{*}{ No. } & \multirow[t]{2}{*}{ Male } & \multirow[t]{2}{*}{ Female } & \multirow[t]{2}{*}{ Age range } & \multirow[t]{2}{*}{ Average age } & \multicolumn{4}{|c|}{ Site (known in 84 cases) } \\
\hline & & & & & & Head & Body & Tail & Whole organ \\
\hline $\begin{array}{l}\text { All } \\
\text { Pure acinar cell } \\
\text { Mixed ductal and acinar cell }\end{array}$ & $\begin{array}{r}105 \\
7 \\
4\end{array}$ & $\begin{array}{r}67 \\
3 \\
2\end{array}$ & $\begin{array}{r}38 \\
4 \\
2\end{array}$ & $\begin{array}{l}25-88 \\
25-84 \\
51-85\end{array}$ & $\begin{array}{l}64 \\
54 \\
64\end{array}$ & $\begin{array}{r}45 \\
5 \\
1\end{array}$ & $\begin{array}{r}20 \\
2 \\
-\end{array}$ & $\frac{16}{3}$ & $\underline{3}$ \\
\hline
\end{tabular}

Table II Acinar cell neoplasms of pancreas

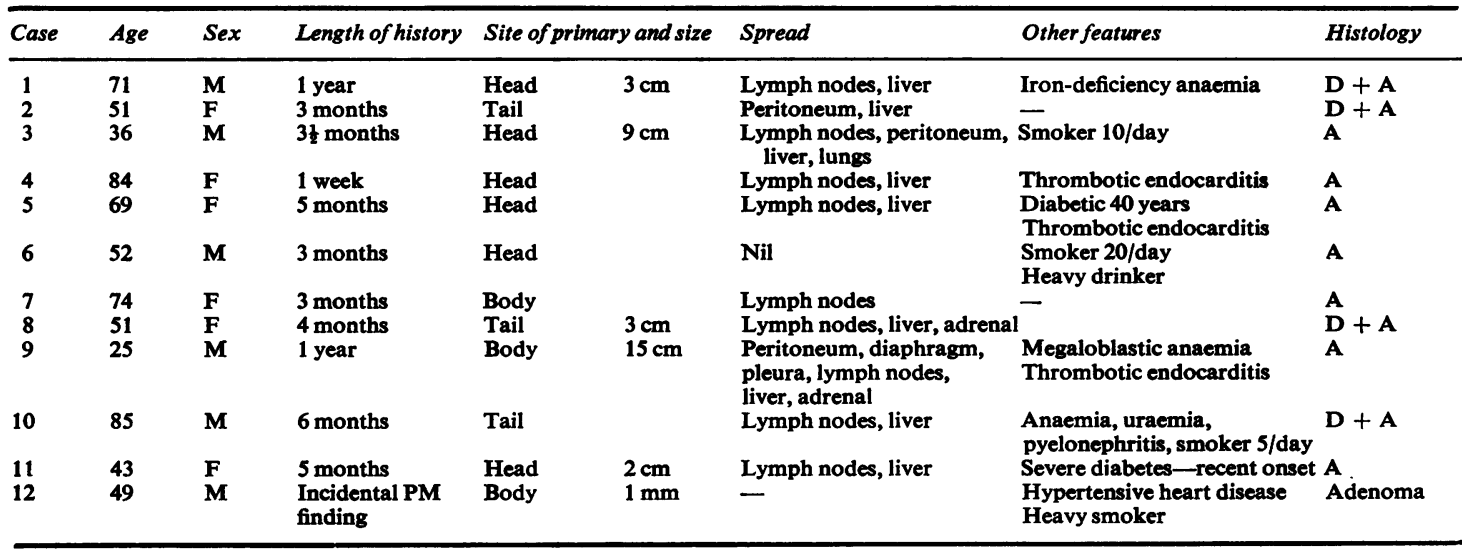

$\mathbf{A}=$ pure acinar cell carcinoma; $\mathbf{D}+\mathbf{A}=$ mixed ductal and acinar cell carcinoma 


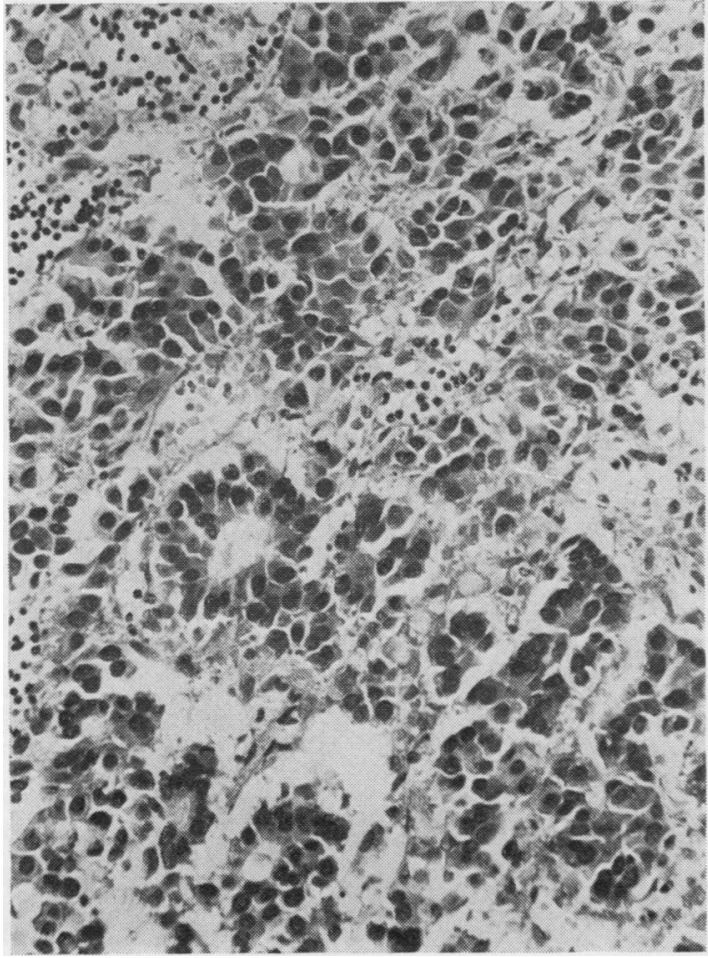

Fig 1

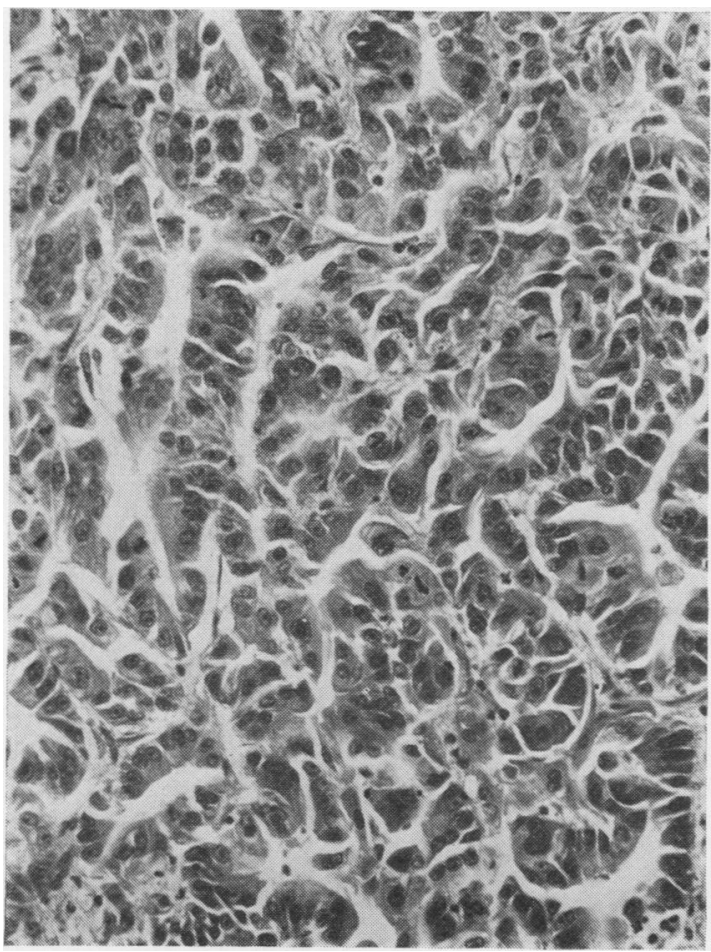

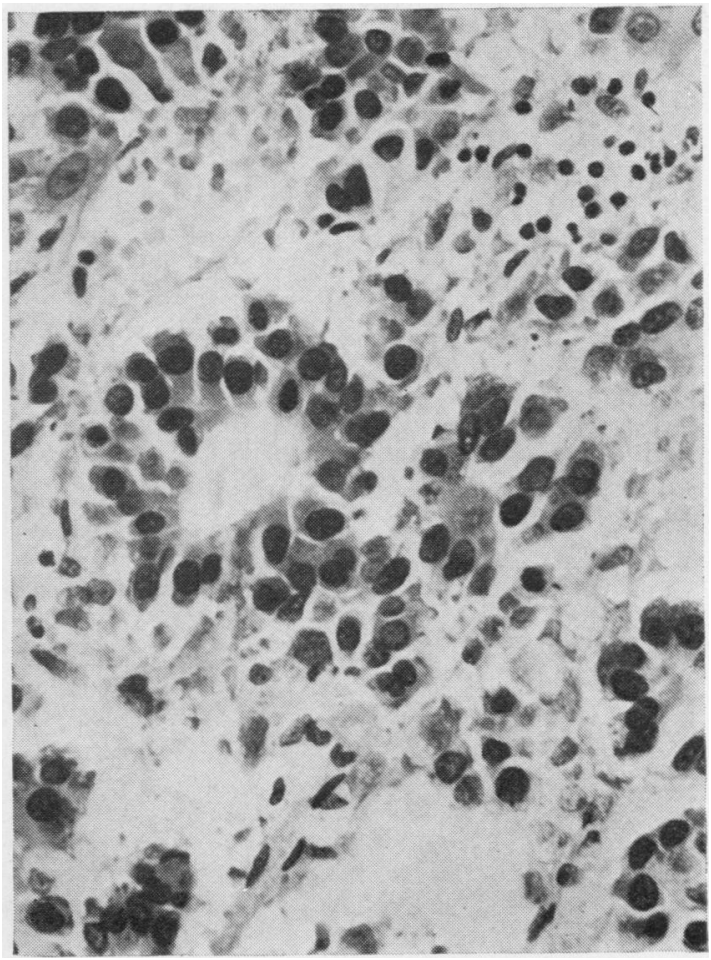

Fig 2

Fig 1 Case 3. Acinar cell carcinoma of pancreas. Solid cellular clumps showing occasional acinar structure. Haematoxylin and eosin $\times 230$.

Fig 2 Case 3. Same field as fig 1. High power to show cellular detail. $H$ and $E \times 410$.

Fig 3 Case 1. Acinar cell carcinoma of pancreas. Note resemblance to normal exocrine pancreas. $H$ and $E \times 230$. 


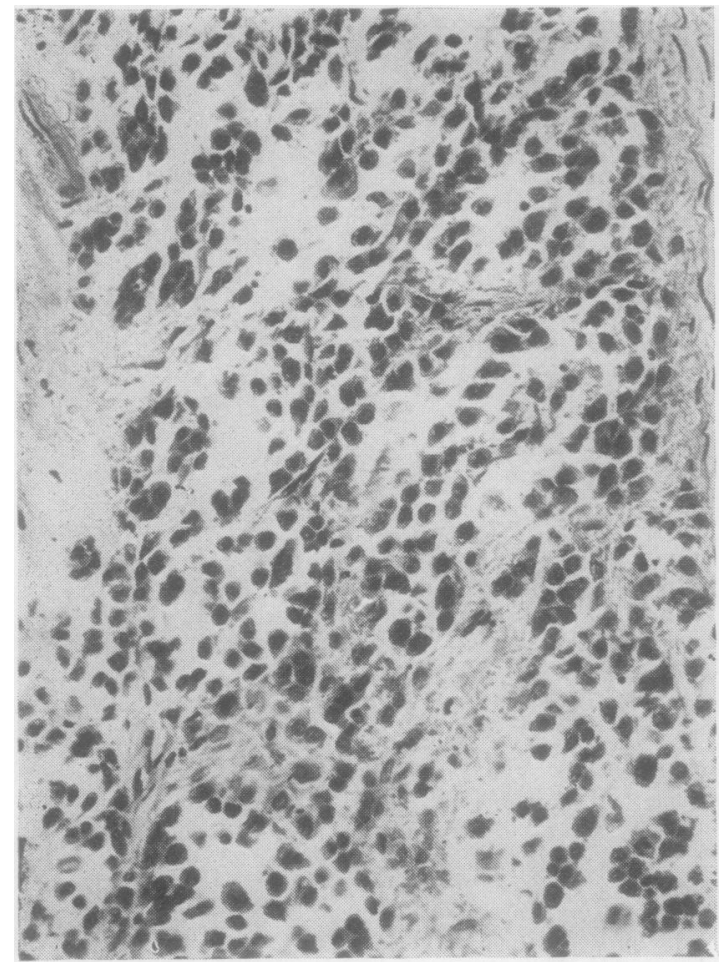

Fig 4

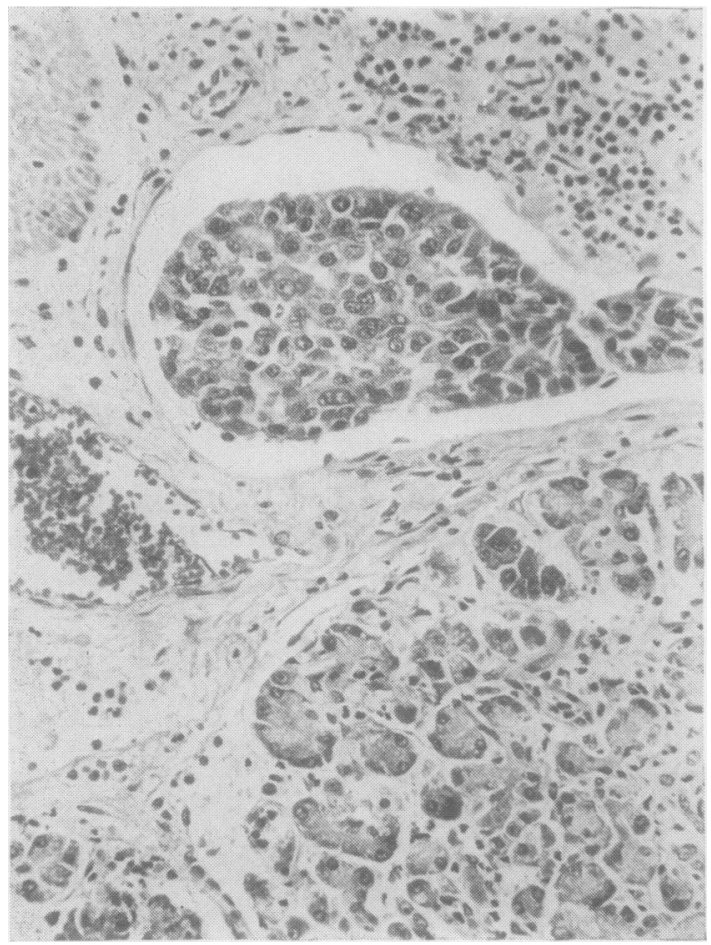

Fig 5

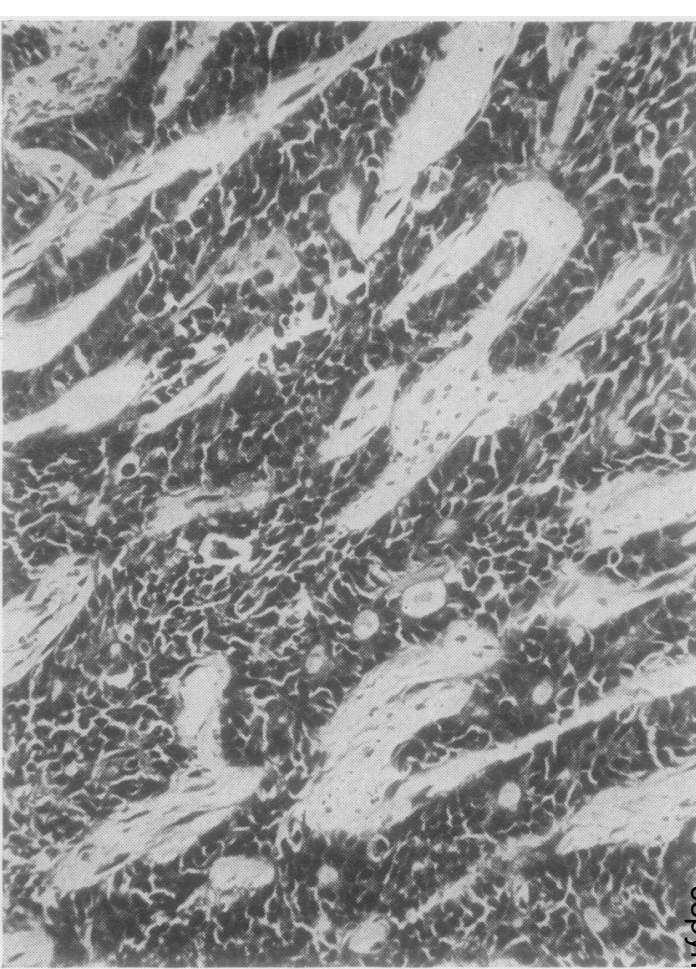

Fig 4 Case 2. Acinar cell carcinoma with alveolar pattern. $H$ and $E \times 230$.

Fig 5 Case 11. Acinar cell carcinoma (liver metastasis). Anastomosing cords of hyperchromatic cells with occasional lumina containing $P A S$ positive material. $H$ and $E \times 230$.

Fig 6 Case 11. Clumps of carcinoma cells in lymphatic channel in pancreas. Carcinoma cells closely resemble acinar cells of exocrine pancreas. (normal pancreas lower right) $H$ and $E \times 230$. 


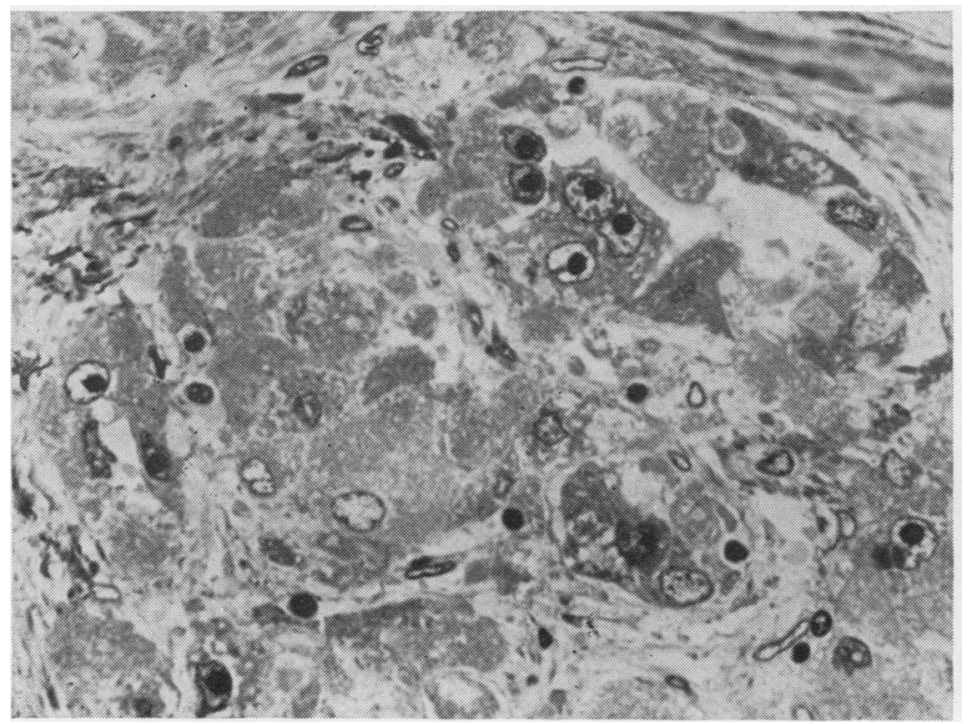

Fig 7 Case 9. High power of carcinoma cells. $1 \mu \mathrm{m}$ Araldite section. Toluidine blue $\times 365$. abundant eosinophil cytoplasm. The cytoplasm of some cells is vacuolated. The nuclei are hyperchromatic and rather pleomorphic. No mitotic figures are seen. No zymogen granules could be identified but neither were they seen in the normal acinar cells of the pancreas because of autolysis. Stains for A and B islet cells, while demonstrating normal islet cells, failed to stain the cells of the adenoma.

\section{ELECTRON MICROSCOPY}

In case 11 (figs 10 and 11) the tumour cells are packed with characteristic homogeneous electrondense zymogen granules up to $250 \mathrm{~nm}$ in diameter. The cytoplasm also contains abundant rough endoplasmic reticulum and numerous mitochondria.

The ultrastructural features were similar in case 9 (fig 12) except that intracytoplasmic granules were less numerous and were less electron-dense; they measured between 250 and $500 \mathrm{~nm}$ in diameter. The tissue in this case had undergone some degree of postmortem autolysis and the patient had also received large doses of cytotoxic drugs which presumably had modified the cellular structure to some extent.

These ultrastructural features closely resemble those of normal pancreatic acinar cells.

\section{Discussion}

The incidence of acinar cell carcinoma in published reports of pancreatic carcinoma varies considerably, eg, 6 out of 39 cases (Leach, 1950), 27 of 202 cases (Miller et al, 1951), and 3 out of 308 cases (Cubilla and Fitzgerald, 1975). These compare with 11 out of 105 cases in the present series, although 4 of the 11 cases were carcinomas of mixed ductal and acinar type so that this series may not be strictly comparable to the others.

Pathologists are familiar with the common adenocarcinomas of pancreas of ductal origin. These are usually well differentiated with a glandular structure. The fibrous stroma may be very abundant, and mucin secretion is frequent. Much less familiar are the adenocarcinomas of acinar cell origin which may occur in a pure form ( 7 of 11 cases) or in a mixed carcinoma where acinar and ductal elements coexist ( 4 cases).

Unless the pathologist is familiar with the acinar cell pancreatic carcinoma its true identity may be overlooked. Such tumours may be erroneously described as undifferentiated carcinomas of unspecified origin. However, electron microscopy shows that the cells of this neoplasm, far from being poorly differentiated, closely resemble the acinar cells of the normal pancreas. When the neoplasm also has a well-developed acinar structure the resemblance to exocrine pancreas can be striking. A further aid in identification is the very fine granularity in the cytoplasm. This feature is likely to be missed if the tissue is inadequately fixed or if the haematoxylin and eosin preparation is not properly differentiated. Sometimes the pattern of the neoplasm is not so characteristic, if, for example, the supporting stroma is abundant or when the cells are arranged in anastomosing cords (fig 5). Such tumours may bear a superficial resemblance to an islet cell carcinoma or even an oat cell carcinoma. In islet cell carcinomas, 


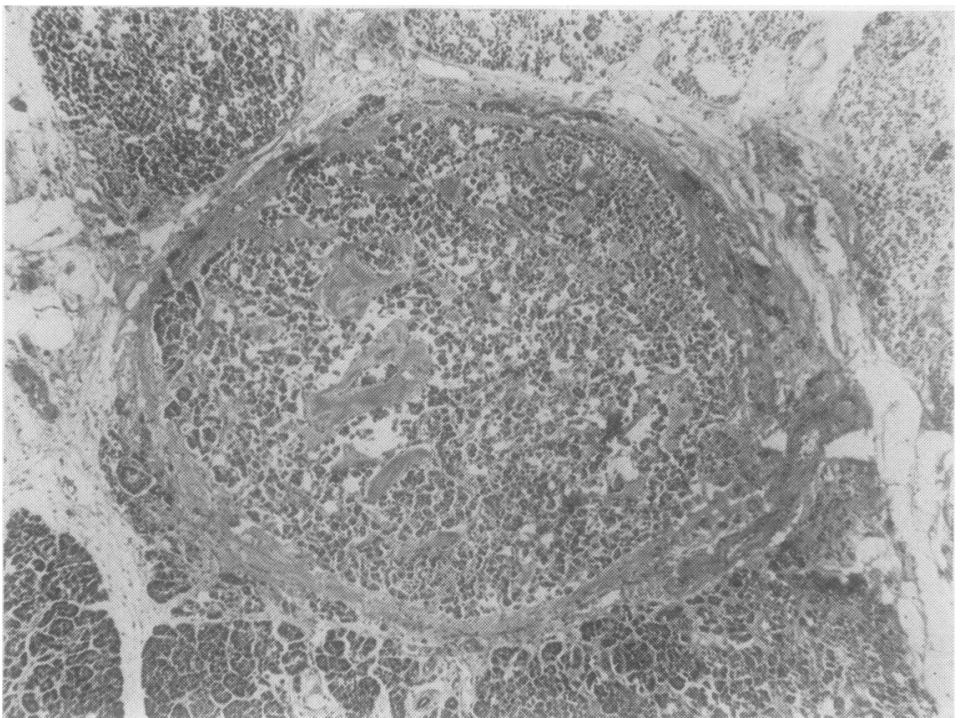

Fig 8 Case 12. Encapsulated adenoma of pancreas, $1 \mathrm{~mm}$ diameter. $H$ and $E \times 18$.

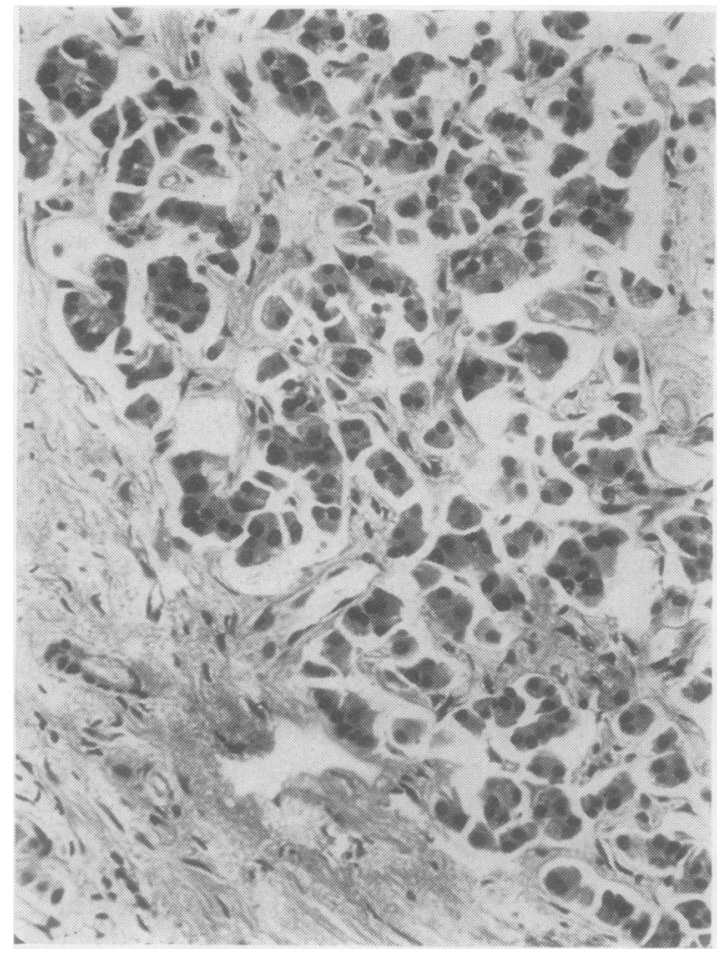

Fig 9a

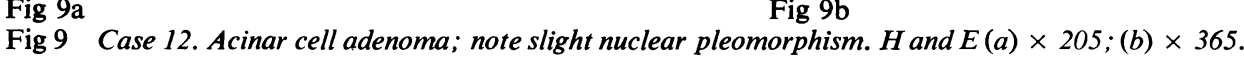

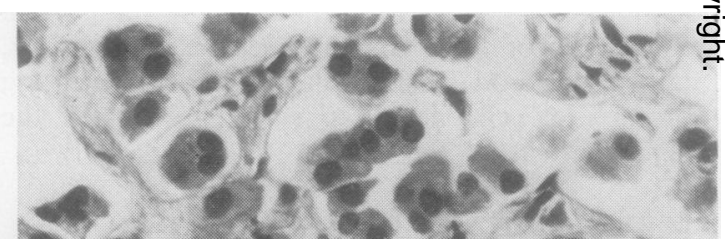

言尝

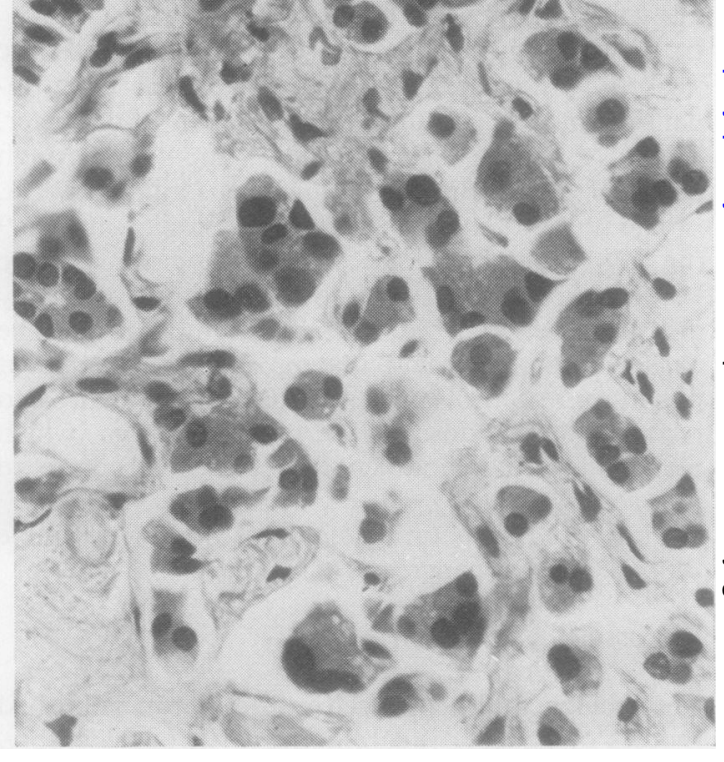

 


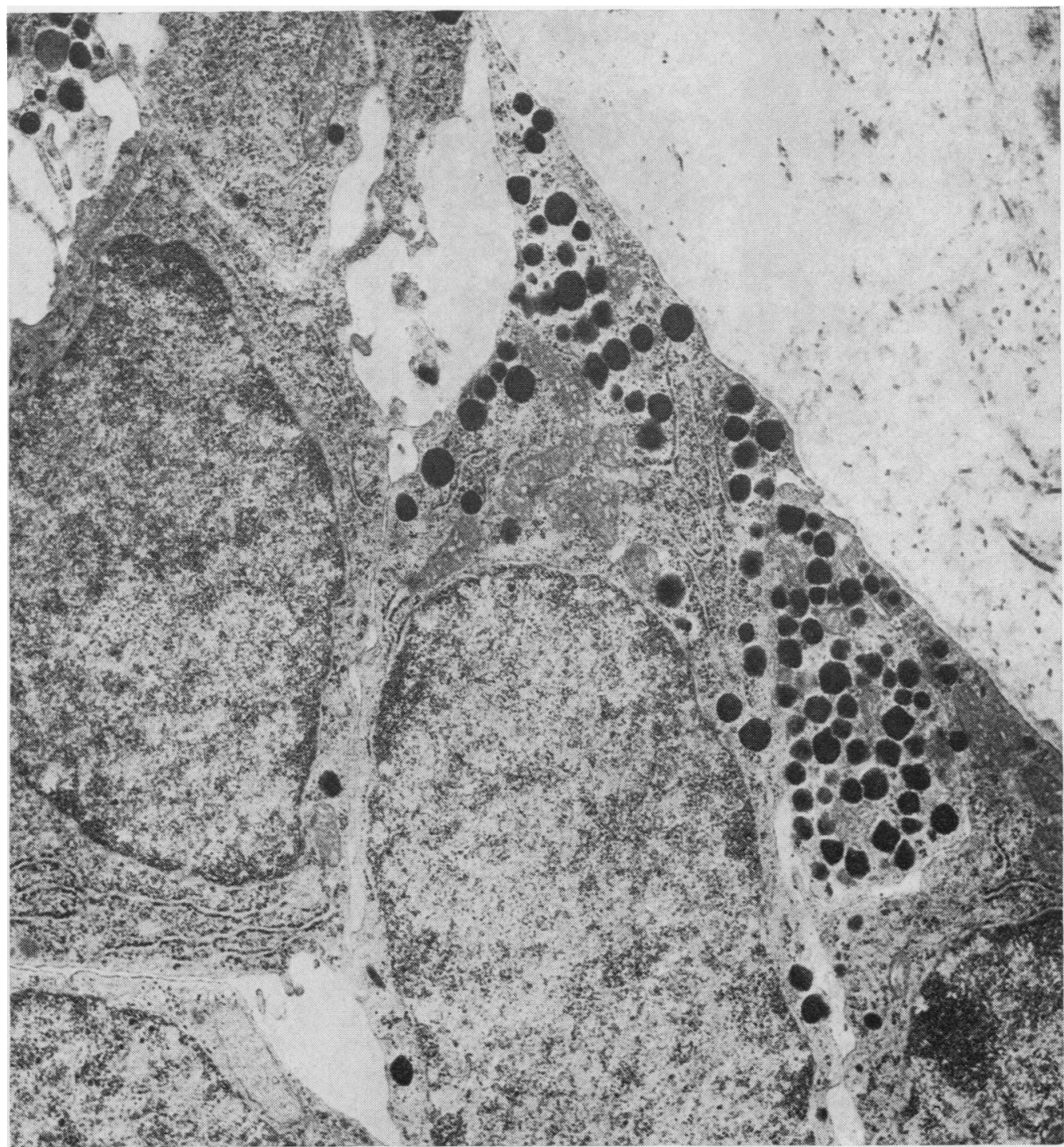

Fig 10 Case 11. Acinar cell carcinoma. Tumour cells contain abundant electron dense granules up to $250 \mathrm{~nm}$ diameter, also abundant rough endoplasmic reticulum. Electron micrograph. Uranylacetate/lead citrate $\times 15000$.

however, there is a tendency for the cells forming the trabeculae to be columnar with their long axes at right angles to the long axis of the trabeculae, giving it a striking and characteristic appearance. I have never seen this in acinar cell carcinomas. In oat cell carcinomas the cytology is distinctive, the cytoplasm being generally very scanty or even barely discernible, while the nucleus, which appears to fill most of the cell, is densely and uniformly haematoxyphilic. Carcinoid tumours, with which these acinar cell tumours might conceivably be confused, have a tendency to form regular solid cell nests although a trabecular pattern also occurs. The nuclei of carcinoid tumours have a degree of uniformity seldom seen in acinar cell carcinomas, and the fine stippling of the nuclear chromatin of carcinoid tumours is not a feature that I have observed in acinar cell carcinomas. Acinar cell tumours occasionally form duct-like spaces which contain PASpositive material. This appearance is not to be 


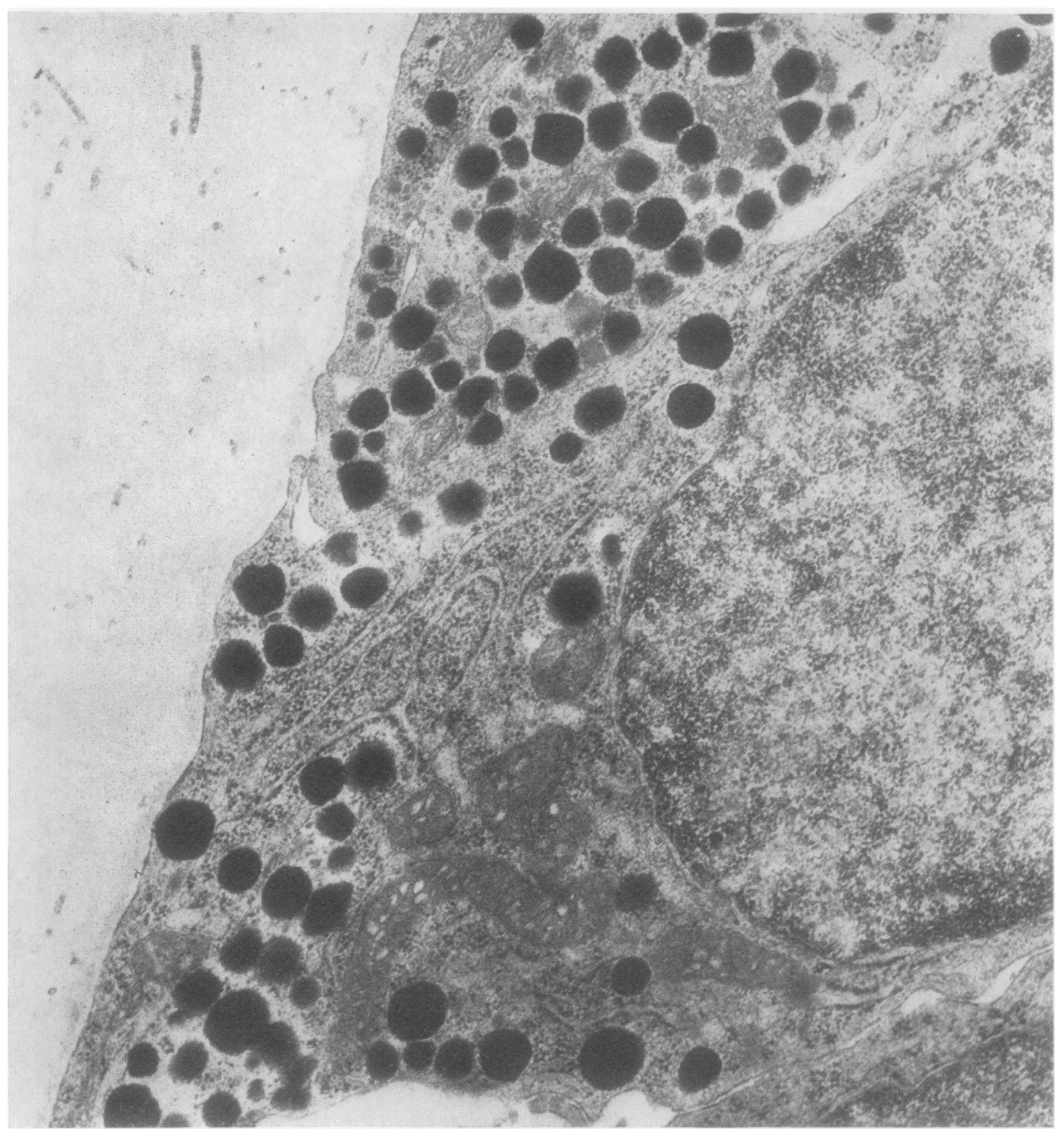

Fig 11 Case 11. Same as fig 10. UA/LC $\times 30000$.

interpreted as showing a ductal origin as the cells forming these duct-like spaces are unquestionably of acinar cell origin. They may be considered as in some ways analogous to the ductal structures of oat cell carcinomas or carcinoid tumours. I have recently seen at biopsy a carcinoma in the head of the pancreas which proved to be a metastasis from a mammary carcinoma. It was forming solid nests and cords of fairly uniform cells set in abundant stroma, a common enough pattern, which might have been misinterpreted as acinar cell carcinoma 0 had the possibility of a metastatic tumour nodule not been considered.

Acinar cell adenoma in humans would appear to $T$ be very rare if the paucity of reports in the pathological literature is anything to go by. Haberer (1927)

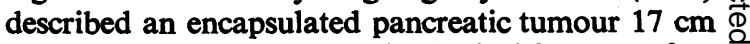
in diameter which had the histological features of an 


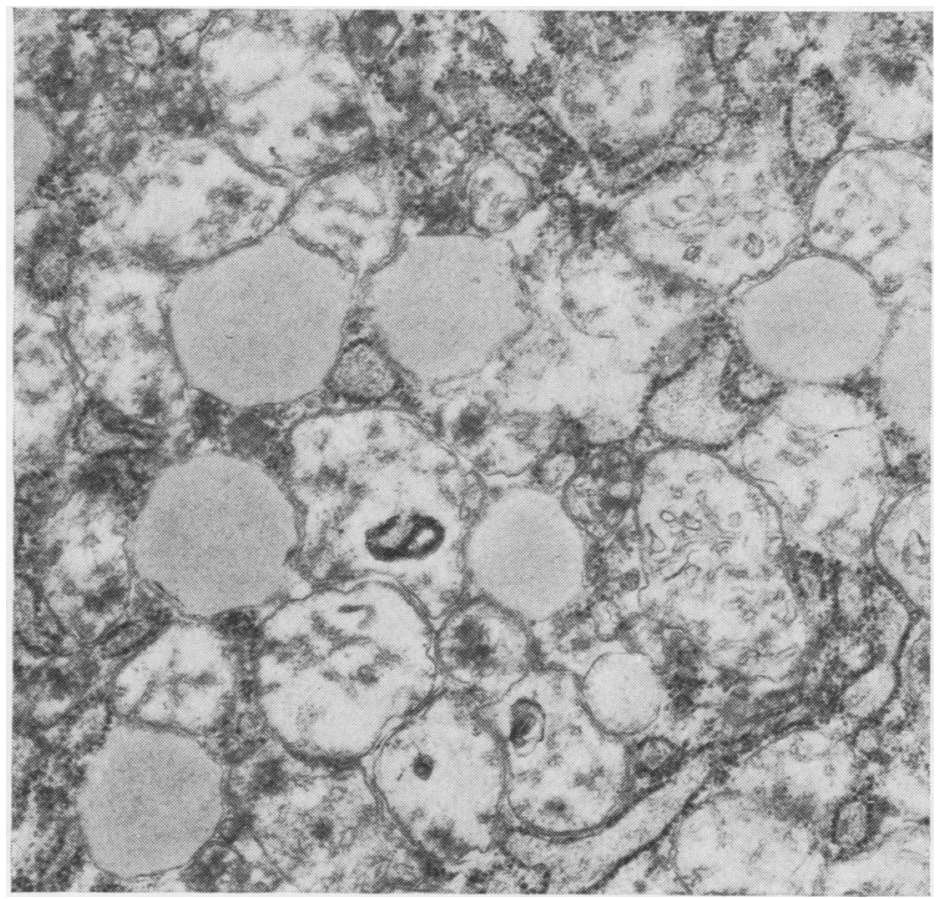

Fig 12 Case 9. Detail of cytoplasm of tumour cell from acinar cell carcinoma showing granules up to $500 \mathrm{~nm}$ diameter and abundant rough endoplasmic reticulum. $U A / L C$ $\times 30000$.

acinar cell neoplasm. Glenner and Mallory (1956) referred to adenomatous hyperplasia of acinar cells but did not find a tumour comparable to the one described by Haberer. They illustrated a microscopic tumour which they called a fibroadenoma; this probably had an acinar cell origin. Acinar cell adenomas have been reported in a number of animals-both of spontaneous origin (Rowlatt and Roe, 1967) and induced experimentally (Longnecker and Crawford, 1974).

Several authors have noted widespread fat necrosis (panniculitis) in association with disseminated acinar cell carcinoma (Hegler and Wohlwill, 1930; Titone, 1936; Auger, 1947; Osborne, 1950; Robertson and Eeles, 1970; Terrasse et al, 1970). This syndrome is characterized by numerous foci of fat necrosis which may occur on the trunk and limbs, together with arthralgia. It is always associated with a large or disseminated carcinoma, and lipase activity can be demonstrated in the tumour. Secretion of the enzyme into the systemic circulation is doubtless responsible for the panniculitis. Three out of the 11 cases in the present series developed a thrombotic endocarditis, which suggests a high incidence of this complication. In all probability secretion products of the tumourvery possibly an enzyme-are the cause of this thrombosis.
The survival rate in cases of pancreatic carcinoma is very poor, and few neoplasms lead to such a rapidly fatal outcome. In one series of 120 necropsy cases (Halpert et al, 1965) the average length of the illness was five months. The average survival time from diagnosis in another series (Moldow and Connelly, 1968) was only 4.3 months. The acinar cell carcinoma appears to be just as malignant as the ductal carcinoma. Of the 11 acinar cell carcinomas in the present series, two survived for one year from the onset of symptoms. The shortest history was one week. The average length of survival was only five months.

Whether external carcinogens may be implicated in the development of human pancreatic carcinoma has yet to be determined although a number of carcinogenic factors have been proposed, namely, smoking, a high fat diet, and nitrosamines. There can be little doubt that in the future epidemiological studies will feature prominently in research into the problem of pancreatic carcinoma. It is quite possible that the classification of histological types of carcinoma will be an important aspect of these studies.

\section{References}

Auger C. (1947). Acinous cell carcinoma of the pancreas, 
with extensive fat necrosis. Arch. Path., 43, 400-405.

Cubilla, A. L. and Fitzgerald, P. J. (1975). Morphological patterns of primary nonendocrine human pancreas carcinoma. Cancer Res., 35, 2234-2248.

Frantz, V. K. (1959). Tumors of the Pancreas. (Atlas of Tumor Pathology, Section 7, fasc. 27-28.) Armed Forces Institute of Pathology, Washington, D.C.

Garcia, H., Pelfrene, A., and Love, L. A. (1975). Pancreatic acinar adenomas. (Letter.) Arch. Path., 99, 621.

Glenner, G. G. and Mallory, G. K. (1956). The cystadenoma and related non-functional tumors of the pancreas. Pathogenesis, classification and significance. Cancer (Philad.), 9, 980-996.

Haberer, H. (1927). Beitrag zu den gutartigen, soliden Geschwülsten des Pankreas. Arch. klin. Chir., 148, 398-403.

Halpert, B., Makk, L., and Jordan, G. L., Jr (1965). A retrospective study of 120 patients with carcinoma of the pancreas. Surg. Gynec. Obstet., 121, 91-96.

Hegler, C. and Wohlwill, F. (1930). Fettgewebsnekrosen in Subcutis und Knochenmark durch Metastasen eines Carcinoms des Pankreasschwanzes. Virchows Arch. path. Anat., 274, 784-802.

Leach, W. B. (1950). Carcinoma of the pancreas: a clinical and pathological analysis of 39 autopsied cases. Amer. J. Path., 26, 333-347.

Longnecker, D. S. and Crawford, B. G. (1974). Hyperplastic nodules and adenomas of exocrine pancreas in azaserinetreated rats. J. nat. Cancer Inst., 53, 573.

Longnecker, D.S. and Curphey, T. J. (1975). Adenocarcinoma of the pancreas in azaserine-treated rats. Cancer Res., 35, 2249-2258.

Miller, J. R., Baggenstoss, A. H., and Comfort, M. W. (1951).
Carcinoma of the pancreas. Effect of histological type and grade of malignancy on its behaviour. Cancer (Philad.), 4, 233-241.

Moldow, R. E. and Connelly, R. R. (1968). Epidemiology of pancreatic cancer in Connecticut. Gastroenterology, 55, 677-686.

Office of Population Censuses and Surveys (1976). Registrar General's Statistical Review of England and Wales for the year 1973. Part 1. (B) Tables. Medical. HMSO, London,

Osborne, R. R. (1950). Functioning acinous cell carcinoma of the pancreas accompanied with widespread focal fat necrosis. Arch. intern. Med., 85, 933-943.

Pour, P., Krüger, F. W., Althoff, J., Cardesa, A., and Mohr, U. (1974). Cancer of the pancreas induced in the Syrian hamster. Amer. J. Path., 76, 349-358.

Robertson, J. C. and Eeles, G. H. (1970). Syndrome associated with pancreatic acinar cell carcinoma. Brit. med. J., 2, 708-709.

Rowlatt, U. and Roe, F. J. C. (1967). Epithelial tumors of the rat pancreas. J. nat. Cancer Inst., 39, 17-25.

Terrasse, J., Moinade, S., de la Guillaumie, B., Bourdeix, G., and Ducroiset, J. D. (1970). Cyto-steatonecrose et cancer du pancréas (à propos d'un cas). Ann. Méd. interne, 121, 935-940.

Titone, M. (1936). Über ungewöhnlich ausgebreitete Fettgewebs - und Gewebsnekrosen bei Pankeaskrebs. Virchows Arch. path. Anat., 297, 416-424.

Willis, R. A. (1967). Pathology of Tumours. 4th edition. Butterworth, London.

Wynder, E. L. (1975). An epidemiological evaluation of the causes of cancer of the pancreas. Cancer Res., 35, 2228-2233. 